\title{
TECTONIC STRESS IN THE STRUCTURES OF THE NORTHERN PRIOKHOTIE (MAGADAN REGION) ACCORDING TO GEOLOGICAL DATA
}

\author{
M.N. Kondratyev $₫$
}

Shilo North-East Interdisciplinary Scientific Research Institute, Far Eastern Branch of the Russian Academy of Sciences, 16 Portovaya St, Magadan 685017, Russia

ABSTRACT. Tectonic fracturing of the Mesozoic and Cenozoic structures was studied in the Northern Priokhotie (Magadan region). The cataclastic analysis method and the statistical method of fracture density analysis were used to reconstruct their state of stress. It is revealed that the folded structures of the Arman'-Viliga synclinorium are subjected to horizontal shearing; the axis of maximum compression is sublatitudinal (azimuth $67^{\circ}$, angle $12^{\circ}$ ); extension is submeridional (azimuth $161^{\circ}$, angle $19^{\circ}$ ). In the Uda-Murgal volcanic arc, horizontal extension with shear takes place; the compression axis is directed to NW (azimuth $259^{\circ}$, angle $29^{\circ}$ ), and the extension axis to NE (azimuth $152^{\circ}$, angle $26^{\circ}$ ). In the Okhotsk-Chukotka volcanogenic belt, volcanic structures are in the field of varying tectonic stresses, from predominant horizontal extension to horizontal shear. The Cenozoic intermontane depressions of the Miocene - Pliocene ages are subjected to horizontal shear; the compression axis is directed to NE (azimuth $214^{\circ}$, angle $29^{\circ}$ ), and the extension axis to NW (azimuth $121^{\circ}$, angle $4^{\circ}$ ). The results of the comparative analysis of the stress states in the above-mentioned areas reliably show that the diversity of the stress state types is statistically related to the structural positions of the studies sites. Such diversity cannot be explained by an influence of active faults, or by any consecutive superposition of deformations at different stages, despite the fact that the deformations have complicated the observed pattern of the stress states. We conclude that each subsequent geodynamic stage only introduced additional elements into the previous structure, but did not completely transform it.

KEYWORDS: Northern Priokhotie; tectonic fault; state of stress

\section{RESEARCH ARTICLE}

Correspondence: Mikhail N. Kondratyev, mkondratyev85@gmail.com
Received: November 29, 2019

Revised: October 2, 2020

Accepted: October 14, 2020

FOR CITATION: Kondratyev M.N., 2021. Tectonic stress in the structures of the Northern Priokhotie (Magadan region) according to geological data. Geodynamics \& Tectonophysics 12 (1), 112-124. doi:10.5800/GT-2021-12-1-0516 


\title{
ТЕКТОНИЧЕСКИЕ НАПРЯЖЕНИЯ В СТРУКТУРАХ СЕВЕРНОГО ПРИОХОТЬЯ (МАГАДАНСКАЯ ОБЛАСТЬ) ПО ГЕОЛОГИЧЕСКИМ ДАННЫМ
}

\author{
М.Н. Кондратьев
}

Северо-Восточный комплексный научно-исследовательский институт им. Н.А. Шило ДВО РАН, 685017, Магадан, ул. Портовая, 16, Россия

АНнОТАЦИЯ. Представлены результаты изучения тектонической трещиноватости в структурах мезозойского и кайнозойского возраста Северного Приохотья (Магаданская область). Напряженные состояния в изучаемых структурах восстанавливались методом катакластического анализа и статистическим методом анализа плотности трещиноватости. Было установлено, что складчатым структурам Армано-Вилигинского синклинория свойственны четко выраженные напряженные состояния типа горизонтального сдвига с осью максимального сжатия в субширотном направлении (аз. $67^{\circ}$, угол $12^{\circ}$ ) и растяжения в субмеридиональном направлении (аз. $161^{\circ}$, угол $19^{\circ}$ ). Структуры Удско-Мургальской вулканической дуги обладают напряженными состояниями типа горизонтального растяжения со сдвигом с осью сжатия в северо-западном направлении (аз. $259^{\circ}$, угол $29^{\circ}$ ) и осью растяжения - в северо-восточном (аз. $152^{\circ}$, угол $26^{\circ}$ ). Вулканоструктуры Охотско-Чукотского вулканогенного пояса характеризуются изменчивым полем тектонических напряжений с вариациями геодинамического типа от преобладающего горизонтального растяжения до горизонтального сдвига. Кайнозойским межгорным впадинам миоцен-плиоценового возраста присущи напряженные состояния типа горизонтального сдвига с осью сжатия в северо-восточном направлении (аз. $214^{\circ}$, угол $29^{\circ}$ ) и осью растяжения в северо-западном направлении (аз. $121^{\circ}$, угол $4^{\circ}$ ). Выполненный сравнительный анализ напряженных состояний показывает, что их разнообразие статистически достоверно связано со структурным положением и не может быть объяснено влиянием активных разломов территории или последовательным наложением разных этапов деформаций на территории, закономерно осложняющим наблюдаемую картину разнообразия напряженных состояний. Таким образом, каждый последующий геодинамический этап вносил в предшествующую структуру только дополнительные элементы, но не преобразовывал ее полностью.

КЛЮЧЕВЫЕ СЛОВА: Северное Приохотье; тектоническая трещина; напряженное состояние

\section{1. ВВЕДЕНИЕ}

Территория Северного Приохотья расположена в области динамического взаимодействия Евразийской и Северо-Американской литосферных плит и Охотской микроплиты [Seno et al., 1996; Hindle et al., 2009], выделяемых на основе современных сейсмических данных, и имеет сложное геологическое строение, обусловленное развитием в течение мезозоя и кайнозоя разнообразных тектонических структур: складчатых, вулканогенных, плутонических, а также новейших орогенных поднятий и впадин.

Несмотря на достаточно подробную геологическую изученность Северного Приохотья, вопросы развития тектонических деформаций в разновозрастных структурах мезозоя и кайнозоя изучены очень слабо. Территория Северного Приохотья находится в пределах юго-восточного фланга сейсмического пояса Черского, однако поле тектонических напряжений (как современных, так и древних) практически не исследовано. Это обусловлено, в частности, преобладающим низким энергетическим классом происходящих здесь землетрясений, а также редкой сетью сейсмостанций, не позволяющей получать достоверные данные для анализа механизмов очагов слабых землетрясений.

Настоящая статья содержит данные диссертационного исследования [Kondratyev, 2019], посвященного изучению тектонических напряжений в основных геологических структурах Северного Приохотья, полученных методами структурной геологии на основе изучения тектонической трещиноватости.

В Северном Приохотье выделяются четыре структурных яруса, в разной степени распространенные на территории региона (рис. 1): 1) позднеюрско-раннемеловые орогенные складчатые структуры Яно-Колымской и Кони-Тайгоносской систем, 2) окраинно-континентальные позднеюрско-раннемеловые осадочные и вулканотектонические структуры Удско-Мургальской дуги, 3) меловые вулканотектонические структуры Охотско-Чукотского вулканогенного пояса (ОЧВП), 4) кайнозойские межгорные впадины [State Geological Map..., 1992; Kotlyar, Rusakova, 2004].

В геодинамической интерпретации позднемезозойской структуры региона выделяются: Вилигинский террейн (фрагмент позднепермского - юрского задугового бассейна), Кони-Тайгоносский террейн (фрагмент позднепалеозойской - раннемезозойской островной дуги), Удско-Мургальская островодужная система (юра - ранний мел), Охотско-Чукотский надсубдукционный вулканогенный пояс мелового возраста, позднеюрско-меловые коллизионные гранитоиды [Khanchuk, 2006].

Позднемезозойские складчатые структуры, принадлежащие Кони-Пьягинскому звену Кони-Тайгоносской складчатой системы и юго-восточному флангу Яно-Колымской системы, разделены Челомджа-Ямским 
глубинным разломом. Юго-восточный фланг Яно-Колымской складчатой системы сложен непрерывно залегающими терригенно-осадочными отложениями, имеющими возраст от перми до поздней юры. Отложения представлены преимущественно толщами алевролитов, имеющими северо-западное простирание, с появлением в верхнем триасе и нижней юре горизонтов песчаников и туфопесчаников. На изученной территории выделяется Армано-Вилигинский синклинорий, сложенный терригенными отложениями юрского возраста, смятыми в линейные и брахиморфные складки, нарушенные сбросо-сдвигами субширотного и северо-восточного простирания [Kotlyar, Rusakova, 2004; State Geological Map..., 2008].

Вдоль южного прибрежного края Северного Приохотья прослеживается линейная структура УдскоМургальской вулканической дуги, которая сложена известково-щелочными вулканитами берриас-валанжинского возраста [Kotlyar, Rusakova, 2004] и комплексом терригенных формаций. Обособленный комплекс терригенно-вулканогенных формаций составляют позднеюрско-раннемеловые толщи (момолтыкичская вулканогенная и хасынская угленосные свиты), которые с несогласием перекрывают структуры Яно-Колымской и Кони-Тайгоносской систем. Тектоническая специфичность и история геологического развития позволяют отнести эти образования к структурам УдскоМургальского окраинно-континентального пояса [Goryachev, 2005]. В диссертации эта зона названа нами Хасынско-Момолтыкичской [Kondratyev, 2019].

Вулканические образования Охотско-Чукотского вулканогенного пояса простираются в широтном направлении на большое расстояние в виде полосы шириной до нескольких сотен километров и залегают на структурах Яно-Колымской и Кони-Тайгоносской мезозойских складчатых систем и в вулканогенно-тектонических комплексах Удско-Мургальской дуги. Вулканиты пояса накапливались в интервале времени от среднего альба до середины кампана [Akinin, Miller, 2011].

В основании типичного разреза вулканитов залегают [Akinin, Miller, 2011] вулканоосадочные породы арманской свиты, фациально замещаемые лавами, брекчиями и туфами андезитов нараулинской толщи. Нараулинская толща перекрывается кислыми туфами и лавами хольчанской свиты. Далее вверх по разрезу они замещаются двупироксеновыми андезитами улынской свиты. Разрез продолжается кислыми игнимбритами ольской свиты. Завершают разрез мощные покровы оливин-плагиоклазовых базальтов мыгдыкитской свиты, формирующие пологонаклонное (10-15 ) плато и с размывом залегающие на нижележащих толщах. Для всех вулканоструктур характерна закономерная приуроченность к магмоподводящим разломам субширотного, северо-восточного и субмеридионального простирания.

Вдоль прибрежной зоны располагается ТауйскоЯмская система кайнозойских межгорных впадин, которые представляют собой широтно ориентированные грабены с амплитудами погружения по сбросам от нескольких сотен метров до 2 км и более. Их размеры в плане варьируются в широких пределах: от нескольких километров в поперечнике (Балахапчинская впадина близ Магадана с неоген-четвертичными осадками мощностью более 600 м) до 150 км в длину и 50 км в ширину (Кава-Тауйская впадина) [Smirnov, 2006].

В составе кайнозойских впадин установлены разнообразные по происхождению и условиям залегания
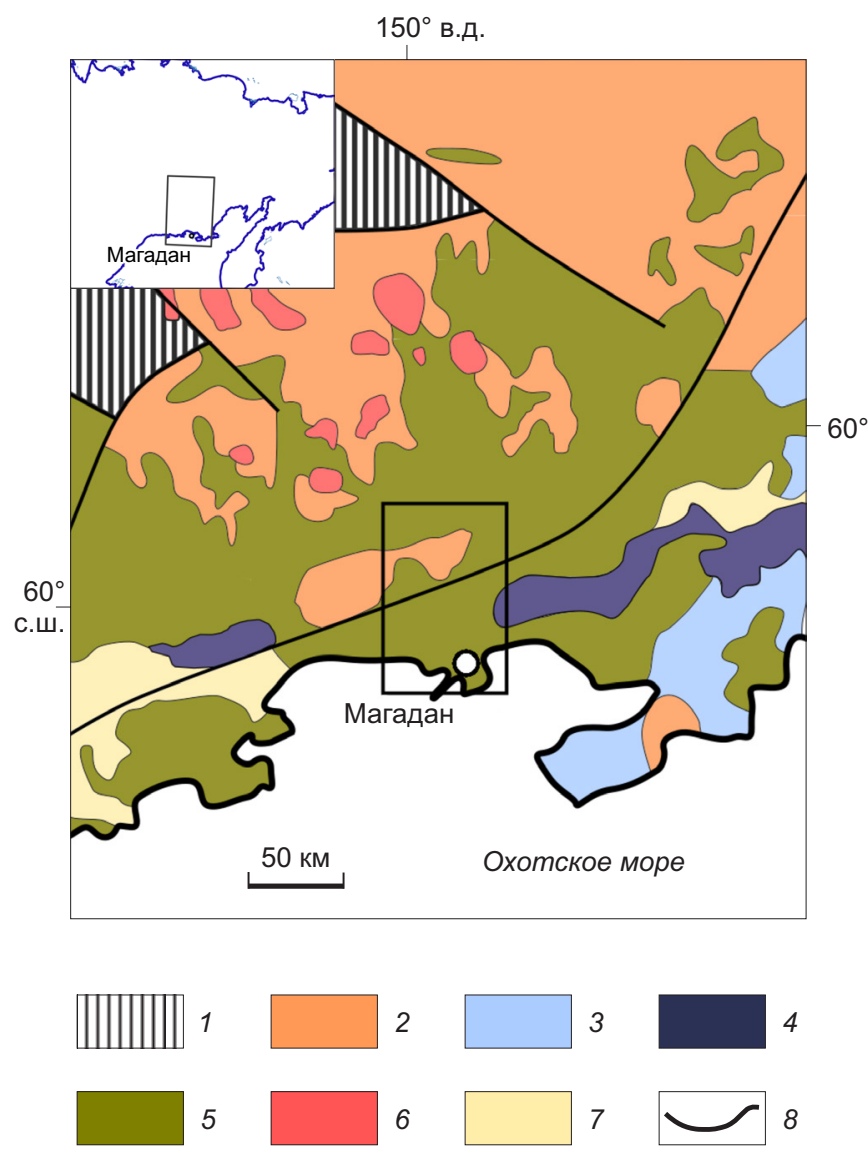

Рис. 1. Фрагмент тектонической карты Дальнего Востока России (по [Khanchuk, 2006], с дополнениями).

1 - Верхоянская пассивная окраина (палеозой - ранний мел); 2 - Вилигинский террейн (фрагмент позднепермского триасового и юрского задугового бассейна); 3 - Кони-Тайгоносский террейн (фрагмент позднемезозойской - раннемезозойской островной дуги); 4 - Удско-Мургальская островодужная система (юра - ранний мел); 5 - надсубдукционный вулканический пояс мелового возраста; 6 - позднеюрские - меловые коллизионные гранитоиды; 7 - кайнозойские осадочные бассейны; 8 - разломы. Рамкой выделено положение изученной территории.

Fig. 1. Fragment of the tectonic map of the Russian Far East (after [Khanchuk, 2006], with additional data).

1 - Verkhoyansk passive margin (Paleozoic - Early Cretaceous); 2 Viliga terrane (fragment of the Late Permian Triassic and Jurassic back-arc basin); 3 - Koni-Taigonos terrane (fragment of Late Mesozoic - Early Mesozoic island arc); 4 - Uda-Murgal island arc system (Jurassic - Early Cretaceous); 5 - Cretaceous suprasubduction volcanic belt; 6 - Late Jurassic - Cretaceous collisional granitoids; 7 - Cenozoic sedimentary basins; 8 - faults. Box - study area. 
континентальные отложения большого возрастного диапазона - от середины палеогена до голоцена. В Магаданской впадине позднемиоценовый возраст имеет нагаевская толща, сложенная ритмично-слоистыми алевролитами, песками с прослоями лигнитов и бурых углей. Выше залегает слой галечников и конгломератов плиоценового возраста, которые выделены под названием «наднагаевские галечники» [Grinenko et al., 1998].

Позднемиоценовые - плиоценовые толщи обнажаются в береговых обрывах бухт Нагаева и Гертнера и оказались доступными в качестве объекта для геологоструктурных исследований.

\section{2. МЕТОДЫ}

Для восстановления напряженных состояний геологических тел был применен хорошо разработанный к настоящему времени комплекс геолого-структурных методов: для изучения зеркал скольжения использовался метод катакластического анализа разрывных смещений Ю.Л. Ребецкого [Rebetsky et al., 2017], для анализа массового замера ориентировок тектонических трещин применяли статистический метод П.Н. Николаева [Nikolaev, 1977]. Для повышения надежности выделения сопряженных пар систем трещиноватости использовали дополнительный статистический критерий [Kondratyev, 2015].

При анализе совокупности данных о полученных в пунктах геолого-структурных наблюдений локальных стресс-состояниях, расположенных в одной геологической структуре, для оценки общего поля напряжений, «внешнего» по отношению к локальным, использовался метод Л.А. Сим [Sim, 1982]. Методика базируется на усреднении, основанном на подборе на стереограмме положения двух взаимно перпендикулярных конических поверхностей, так чтобы в одном из конусов не было ни одного выхода оси сжатия, а в другом конусе не было ни одного выхода оси растяжения. В таком случае ось растяжения общего поля напряжений для такой совокупности локальных стресс-состояний будет совпадать с осью первого конуса, а ось сжатия общего поля напряжений - с осью второго конуса.

В данной работе подбор положений конусов сжатия и растяжения проводили методом наименьших квадратов. Критерием, по которому осуществляли оптимизацию положения конуса растяжения, являлась сумма углов между каждой из осей растяжений локальных стресс-состояний и текущей осью конуса. То же самое выполняли для конуса сжатия. Таким образом, для данного набора локальных стресс-состояний выбирается определенное положение взаимно перпендикулярных конусов сжатия и растяжения, для которых минимальна сумма углов между осью конуса и соответствующей осью локального стресс-состояния.

\section{3. РЕЗУЛЬТАТЫ}

На территории Северного Приохотья было выбрано 12 опорных участков в различных структурно-геологических обстановках, на которых проведены массовые замеры элементов залегания тектонической трещиноватости и измерение ориентации борозд скольжений (табл. 1, рис. 2).

В мезозойских складчатых структурах анализ тектонической трещиноватости выполняли на трех участках, расположенных в пределах Армано-Вилигинского

Таблица 1. Исследованные участки в различных геологических обстановках Северного Приохотья и реконструкция напряженных состояний

Table 1. Studied sites in different geological settings of the Northern Priokhotie, and stress state reconstructions

\begin{tabular}{|c|c|c|c|c|c|c|}
\hline Участок & $\begin{array}{c}\text { Координаты, } \\
\text { с.ш., в.д. }\end{array}$ & $\begin{array}{c}\text { Число } \\
\text { пунктов }\end{array}$ & $\begin{array}{c}\text { Метод } \\
\text { анализа }\end{array}$ & $\begin{array}{c}\text { Ось } \\
\text { сжатия }\end{array}$ & $\begin{array}{c}\text { Ось } \\
\text { растяжения }\end{array}$ & $\begin{array}{c}\text { Тектоническая } \\
\text { позиция }\end{array}$ \\
\hline Хета & $61.0^{\circ}, 151.7^{\circ}$ & 12 & Николаев & $90^{\circ}, 10^{\circ}$ & $0^{\circ}, 0^{\circ}$ & $\mathrm{ABC}$ \\
\hline Армань & $60.6^{\circ}, 150.6^{\circ}$ & 27 & Николаев & $90^{\circ}, 0^{\circ}$ & $0^{\circ}, 0^{\circ}$ & $\mathrm{ABC}$ \\
\hline Магадавен & $60.5^{\circ}, 151.0^{\circ}$ & 1 & МКА & $15^{\circ}, 9^{\circ}$ & $243^{\circ}, 76^{\circ}$ & $\mathrm{ABC}$ \\
\hline Ойра & $59.8^{\circ}, 149.8^{\circ}$ & 6 & Николаев & $261^{\circ}, 31^{\circ}$ & $182^{\circ}, 34^{\circ}$ & XM3 \\
\hline Хасын & $60.1^{\circ}, 150.8^{\circ}$ & 1 & МКА & $326^{\circ}, 28^{\circ}$ & $45^{\circ}, 23^{\circ}$ & XM3 \\
\hline Дондычан & $60.5^{\circ}, 150.9^{\circ}$ & 1 & МКА & $87^{\circ}, 42^{\circ}$ & $324^{\circ}, 38^{\circ}$ & ОЧВП \\
\hline Колхида & $60.6^{\circ}, 151.6^{\circ}$ & 1 & МКА & $260^{\circ}, 32^{\circ}$ & $61^{\circ}, 73^{\circ}$ & ОЧВП \\
\hline Карамкен & $60.2^{\circ}, 151.1^{\circ}$ & 1 & МКА & $78^{\circ}, 62^{\circ}$ & $290^{\circ}, 30^{\circ}$ & ОЧВП \\
\hline Нельканджа & $60.2^{\circ}, 150.7^{\circ}$ & 5 & Николаев & $335^{\circ}, 10^{\circ}$ & $65^{\circ}, 0^{\circ}$ & ОЧВП \\
\hline Ола & $60.6^{\circ}, 151.4^{\circ}$ & 10 & Николаев & $262^{\circ}, 50^{\circ}$ & $350^{\circ}, 30^{\circ}$ & ОЧВП \\
\hline
\end{tabular}

Примечание. АВС - Армано-Вилигинский синклинорий; ХМЗ - Хасыно-Момолтыкичская зона; ОЧВП - Охотско-Чукотский вулканогенный пояс (Хасынское звено); КВ - кайнозойские впадины; МКА - метод катакластического анализа; координаты указаны для центральной точки участка; для каждого участка указаны усредненные напряженные состояния. Ориентировка осей напряжения представлена азимутом и углом погружения.

Note. ABC - Arman-Viliga synclinorium; XMЗ - Khasyn-Momoltykich zone; ОЧВП - Okhotsk-Chukotka volcanogenic belt (Khasyn segment); KB Cenozoic depressions; MKA - cataclastic analysis method. Coordinates are given for the center points of observation sites. For each site, an average stress state is given. Stress axis orientation - azimuth and dip angle. 

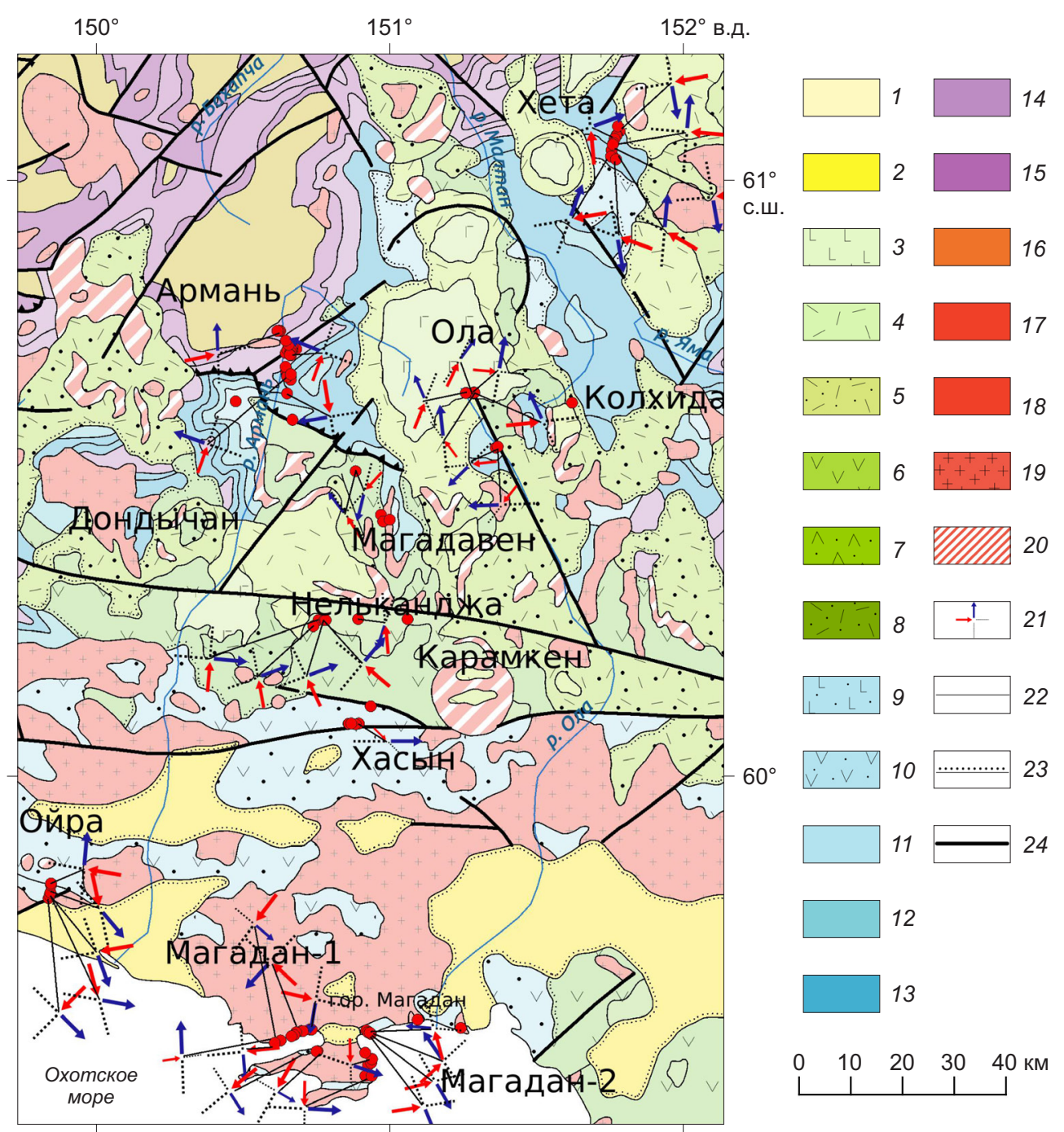

Рис. 2. Размещение опорных участков геолого-структурных наблюдений и восстановленные ориентации осей $\sigma_{1}$ и $\sigma_{3}$. Геологическая основа по [State Geological Map..., 1992].

1 - четвертичные отложения; 2 - конгломераты, песчаники, аргиллиты, алевролиты неогенового возраста; 3-5 - верхнемеловые вулканиты: 3 - базальты, андезибазальты, туфы базальтов, туфы риолитов мыгдыкитской свиты, 4 - игнимбриты риолитов, риодацитов, дацитов ольской свиты, 5 - туфы, игнимбриты дацитов, риодацитов и риолитов хольчанской свиты; 6 - песчаники, конгломераты, андезиты, андезибальты нерасчленённых отложений арманской свиты нижнего - верхнего мела; 7-10 - нижнемеловые вулканиты: 7 - андезиты, андезибазальты, дациты, туфы андезитов, дацитов нанкалинской толщи, 8 - туфоконгломераты, туфопесчаники, алевролиты, аргиллиты кирикской толщи, 9, 10 - андезиты, андезибазальты, базальты, их туфы, туфопесчаники, туфоалевролиты момолтыкичской свиты верхней юры - нижнего мела; 11-13 - стратифицированные отложения юрского возраста (аргиллиты, алевролиты, песчаники); 14-16 - стратифицированные отложения триасового возраста (аргиллиты, алевролиты, песчаники); 17, 18 - стратифицированные отложения пермского возраста (аргиллиты, алевролиты, песчаники); 19 - гранитные и гранодиоритные интрузии мелового возраста; 20 - субвулканические тела кислого состава мелового возраста; 21 - пункты геолого-структурных наблюдений и восстановленные в них ориентации осей сжатия и растяжения, пунктиром показан выход осей на верхнюю полусферу; 22 - геологические границы; 23 - то же, с угловым несогласием; 24 - разломы.

Fig. 2. Reference sites for geological and structural observations, and reconstructed orientations of axes $\sigma_{1}$ and $\sigma_{3}$. Geological data after [State Geological Map ..., 1992].

1 - Quaternary deposits; 2 - Neogene conglomerate, sandstone, mudstone, siltstone; 3-5 - upper Cretaceous volcanic rocks: 3 - basalt, basaltic andesite, basalt tuff, rhyolite tuff (Makdyk Formation), 4 - rhyolite, rhyodacite, dacite ignimbrites (Ool Formation), 5 - tuff, and dacite, rhyodacite, rhyolite ignimbrites (Kholchan Formation); 6- sandstone, conglomerate, andesite, andesibasalt of undivided deposits (lower - upper Cretaceous Arman Formation); 7-10 - lower Cretaceous volcanic rocks: 7 - andesite, andesibasalt, dacite, andesite tuff, dacite (Nankala strata), 8 - tuff-conglomerate, tuff-sandstone, siltstone, mudstone (Kirik strata), 9, 10 - andesite, andesibasalt, their tuffs, tuff-sandstone, tuff-siltstone (upper Jurassic - lower Cretaceous Momoltykich Formation); 11-13 - stratified Jurassic deposits (mudstone, siltstone, sandstone); 14-16 - stratified Triassic deposits (mudstone, siltstone, sandstone); 17, 18 - stratified Permian deposits (mudstone, siltstone, sandstone); 19 - Cretaceous granite and granodiorite intrusions; 20 - Cretaceous acid subvolcanic bodies; 21 geological and structural observation sites, and reconstructed orientations of compression and extension axes (dashed line - axes at the upper hemisphere); 22 - geological boundaries; 23 - geological boundaries with angular nonconformity; 24 - faults. 
синклинория, вблизи северной границы Хасынского звена ОЧВП.

Участок Хета находится в бассейне р. Малтан в зоне динамического влияния Хетинского разлома, который трассируется в субширотном направлении через долину р. Хета от р. Малтан на западе до р. Эльген на востоке на расстояние около 90 км [Smirnov, Kondratyev, 2011]. Изучению подвергалась трещинная структура в обнажениях юрских алевролитов в бортах р. Хета.

Участок Армань располагается в верхнем течении p. Армань и находится в зоне динамического влияния
Иня-Ямской зоны разломов субширотного простирания и Арманского разлома северо-восточного простирания [Kondratyev, Smirnov, 2013]. Изучение тектонической трещиноватости выполняли в обнажениях стратифицированных отложений - аргиллитов и алевролитов триасового и юрского возраста.

Участок Магадавен находится в бассейне р. Мадагавен (левый приток р. Армань) в пределах южного выступа Хасын-Магадавенского относительного поднятия [State Geological Map..., 2001], где обнажен фрагмент Дондычан-Нелканджинской брахисинклинали. (a)

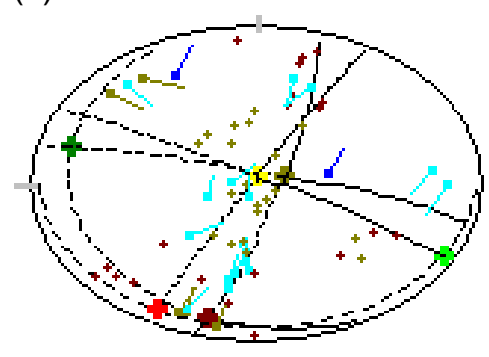

(в)

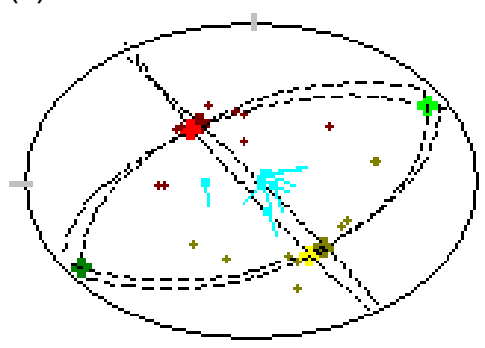

$(\partial)$

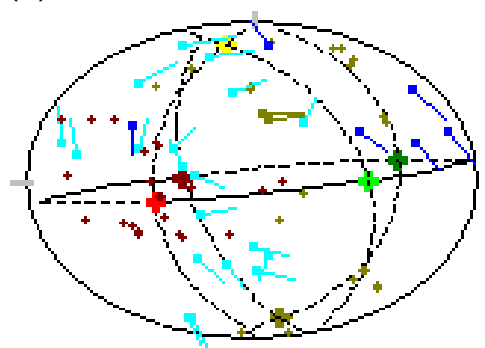

(б)

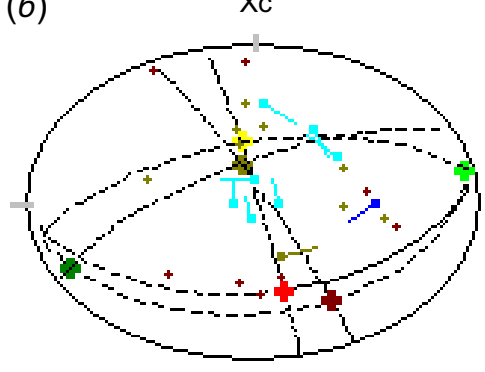

(2)

Дн-2

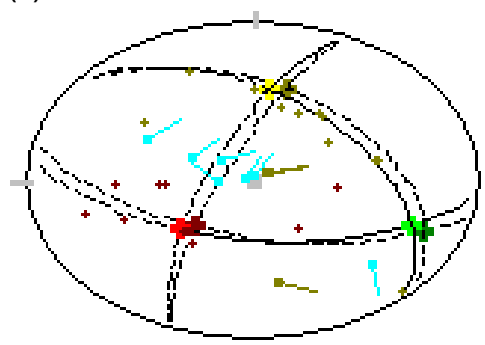

Kp

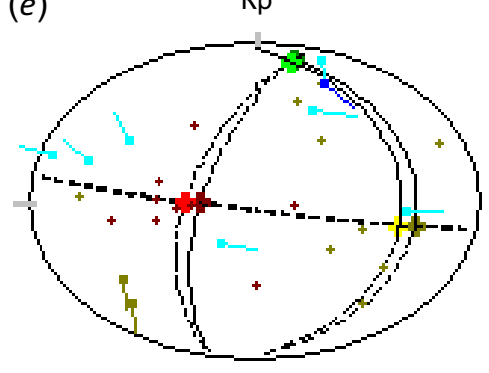

Рис. 3. Эллипсоиды напряжений, полученные методом MКА [Rebetsky et al., 2017] на основе ориентировок борозд скольжений. Мг - Магадавен, Хс - Хасын, Дн-1, Дн-2 - Дондычан, Кл - Колхида, Кр - Карамкен.

На стереограммах показаны выходы установленных ориентаций осей главных нормальных напряжений на нижнюю полусферу (темные оттенки красного, желтого и зеленого цвета). На этой же стереограмме присутствуют трещины, участвующие в выделенном этапе, изображенные в виде векторов направления смещения на этих трещинах, построенные в полюсах их нормалей. Бирюзовым цветом отмечены векторы, соответствующие трещинам, хорошо удовлетворяющим критериям однородности выборки, темно-желтым - векторы трещин, умеренно удовлетворяющим критериям однородности, синим - векторы трещин, не вошедших в однородную выборку.

Fig. 3. Stress ellipsoids reconstructed from the orientations of slide traces (cataclastic analysis method [Rebetsky et al., 2017]). Мг - Magadaven, Xc - Khasyn, Дн-1, Дн-2 - Dondychan, Кл - Kolkhida, Кр - Karamken.

Stereograms show the orientations of the main normal stress axes at the lower hemisphere (dark shades of red, yellow and green). In the same stereogram, fractures belonging to the selected stage are shown as displacement direction vectors at normal poles. Colour codes of vectors: turquoise - fractures meet the criteria of uniformity of the given data set; dark yellow - fractures moderately satisfy the uniformity criteria; blue - fractures are not included in the uniform data set. 
Массовые замеры трещиноватости, а также измерения ориентировок и направлений борозд в милонитизированных зеркалах скольжения проводили в среднеюрских песчаниках (рис. 3, а).

В пределах вулканотектонических структур ХасыноМомолтыкичской зоны Удско-Мургальской дуги изучение тектонической трещиноватости выполняли на трех участках в вулканитах момолтыкичской свиты, прорванных меловыми субвулканитами, и в береговых обнажениях меловых гранитоидных интрузий Магаданского батолита.

Участок Хасын размещается в бассейне реки с одноименным названием в окрестностях пос. Палатка Магаданской области. Пункты геолого-структурного изучения располагались в обнажениях андезитов момолтыкичской свиты, на правобережье р. Хасын. Породы свиты в обнажениях слабодислоцированны и залегают субгоризонтально (рис. 3, б).

Участок Ойра находится в 50 км к западу от г. Магадана, в бассейне р. Ойра, впадающей в Охотское море и пересекающей в субмеридиональном направлении Горгычанский и Каменный хребты. Пункты геолого-структурного изучения располагались в обнажениях андезитов и андезибазальтов момолтыкичской свиты (рис. 4, а).

(a)

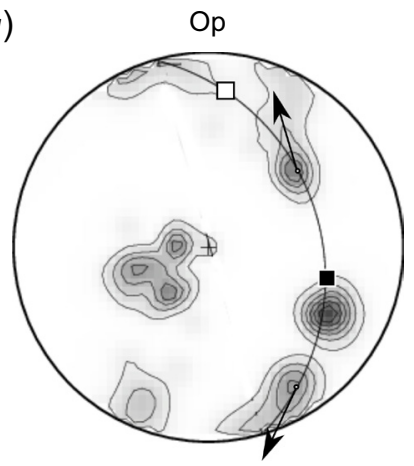

(в)

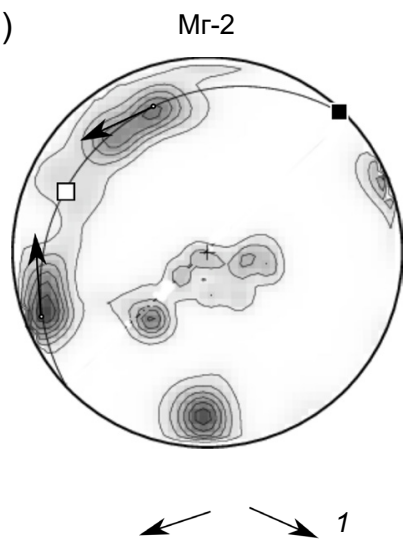

Участок Магадан-1 расположен на побережье Охотского моря в районе г. Магадана в пределах Магаданского гранитоидного массива (батолита), прорывающего вулканогенные толщи позднеюрско-раннемелового возраста. Трещинная сеть в изученных обнажениях обладает характерным обликом, а именно ярко выраженным поясом вращения трещиноватости. При этом вся совокупность трещин на каждом обнажении лежит исключительно в одном поясе (рис. 4, б).

Тектоническую трещиноватость вулканоструктур изучали в пределах Хасынского звена ОЧВП в обнажениях меловых вулканитов.

Участок Дондычан расположен в верховье р. Дондычан (бас. р. Армань) в северо-восточной части Арманской вулканоструктуры ОЧВП. Он приурочен к выделенной здесь палеосейсмодислокации [Smirnov et al., 2018]. На участке широко распространены разрывные нарушения, часть из которых обнаруживает явные признаки современной активности. Наиболее крупное из них проходит вдоль правого борта р. Дондычан, где расположен комплекс палеосейсмодислокаций. Для восстановления напряженного состояния на стенке отрыва сейсмогенного скального оползня и в непосредственной близости от него была изучена сеть трещиноватости

(6)

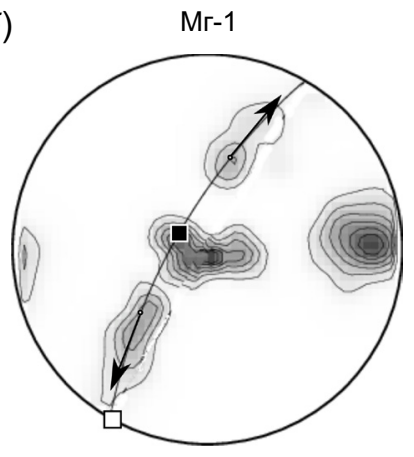

(2)

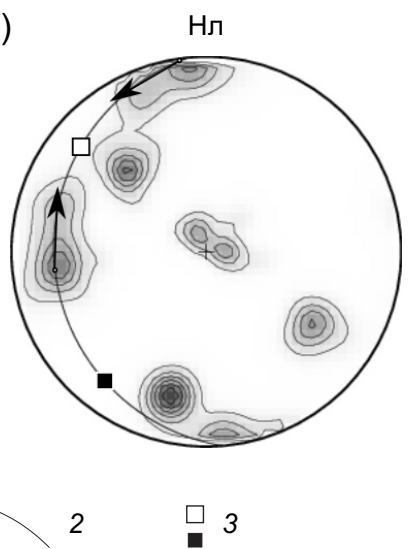

Рис. 4. Пример стереограмм плотности трещиноватости с восстановленными ориентациями осей сжатия и растяжения в отдельных пунктах наблюдений.

Op - Ойра, Мг-1, Мг-2 - Магадан, Нл - Нельканджа. 1 - асимметричные разбросы плотнотности трещиноватости; 2 - главная кинематическая плоскость; 3 - выходы осей $\sigma_{1}$ и $\sigma_{3}$.

Fig. 4. Examples of fracture density stereograms, and the orientations of reconstructed axes compression and extension. Op - Oira, Мг-1, Мг-2 - Magadan-1, Нл - Nelkandzha. 1 - asymmetric scatter of fracture density; 2 - main kinematic plane; 3 - axes $\sigma_{1}$ and $\sigma_{3}$. 

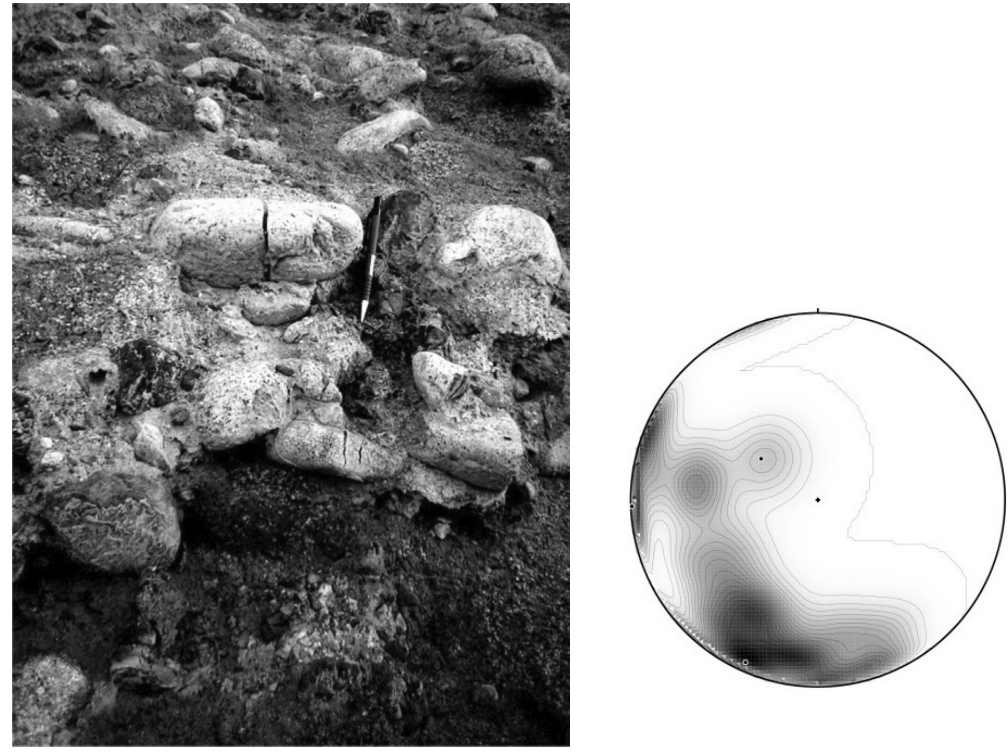

Рис. 5. Зона рассланцевания валуна и гальки в конгломератах нагаевской толщи, рассеченная эшелонированными тектоническими трещинами, и стереограмма массовых замеров трещиноватости.

Fig. 5. Schistosity zone in conglomerates (Nagaev strata), which is cut by echeloned tectonic fractures. Fracture stereogram based on mass measurements.

в субвулканических породах нанкалинского комплекса, слагающих палеосейсмодислокацию (см. рис. 3, в, г).

Участок Колхида находится в верховьях одноименного ручья вблизи золотосеребряного месторождения Колхида в Верхнемалтанской интрузивно-купольной структуре, сложенной туфами и игнимбритами кислого состава позднемелового возраста. Массовые замеры трещиноватости проводили в туфах и игнимбритах риолитов хольчанской свиты, а также в обнаруженных многочисленных кварц-карбонатных прожилках с бороздами скольжения (см. рис. 3 , д).

Участок Нельканджа расположен в бассейне р. Нельканджа и сложен туфоконгломератами нижнего мела, с размывом залегающими на момолтыкичской свите (рис. 4, г).

Участок Ола расположен в окрестностях крупной гравитационной палеосейсмодислокации в верховьях р. Ола, в 125 км к северо-северо-востоку от г. Магадана [Smirnov et al., 2017]. Массовый замер элементов залегания плоскостей тектонической трещиноватости был выполнен в вулканических комплексах ольской и мыгдыкитской свиты как в плоскости отрыва палеосейсмодислокации, так и вне ее, на скальных выступах склона на противоположном берегу р. Ола.

Для изучения тектонической трещиноватости в кайнозойских впадинах были выбраны морские береговые обрывы в бухте Гертнера на участке Магадан-2. Собран материал по ориентировке трещин в верхнемиоценовых конгломератах нагаевской толщи, залегающих в нижней части берегового уступа в бухте Гертнера. Отдельные гальки, входящие в состав конгломератов, разбиты субвертикальными трещинами (рис. 5). Плоскости трещин имеют устойчивую широтную ориентацию на протяжении всего обнажения, и часто след одной и той же плоскости разбивает серию галек, лежащих на ее линии. Установленные дислокации, очевидно, связаны с влиянием Нагаевского и Веселого активных разломов [Smirnov et al., 2000].

\section{4. ОБСУЖДЕНИЕ РЕЗУЛЬТАТОВ}

Для того чтобы весь комплекс решений, полученный на 12 участках в разных тектонических обстановках, разделить на отдельные группы, был проведен анализ массива результатов реконструкций. На рис. 6 показана диаграмма, на которой изображено положение оси на зенит относительно осей $\sigma_{1}, \sigma_{2}$ и $\sigma_{3}$ для изученных пунктов напряжений. Как видно из диаграммы, в подавляющем большинстве изученных пунктов ось на зенит лежит в пределах $30^{\circ}$ от оси $\sigma_{2}$, что позволяет отнести их по типу напряженного состояния к горизонтальному сдвигу и горизонтальному растяжению со сдвигом. Исключение составляют участки Магадавен, Хасын, отдельные пункты наблюдений на участках Магадан-1 и Нельканджа (тип напряжения - горизонтальное сжатие с осью сжатия, лежащей в северных румбах) и участки Колхида, Дондычан, Карамкен, Ола (горизонтальное растяжение с осью растяжения, ориентированной незакономерно) (рис. 7).

При оценке напряженно-деформированного состояния изучаемой территории мы исходили из того, что на итоговую картину распределения напряженных состояний будут оказывать влияние одновременно множество факторов, среди которых в качестве основных можно выделить общее региональное поле напряжений, рисунок сети активных разломов, геологическую структуру. Кроме того, наблюдаемые напряженные состояния могут быть осложнены последовательным наложением разных этапов деформации, что приведет 
к закономерному усложнению картины при переходе от более молодых структур к более древним. Для того чтобы оценить, в какой степени каждый из этих факторов влияет на итоговую картину, мы применили анализ, предложенный далее.

Если верен сценарий с последовательным наложением разных этапов деформации, вариации напряжений должны коррелировать с возрастом структур, в которых он восстановлен, - чем древнее структура, тем больший набор разнообразных данных она в себе несет, т.е. на территории Северного Приохотья в структурах кайнозойских впадин должны присутствовать следы только последней фазы деформации, а в структурах складчатого основания пояса - весь набор фаз деформаций, через которые прошел регион. В этом случае складчатые структуры основания ОЧВП, а также структуры Удско-Мургальской дуги должны быть структурами с наибольшей насыщенностью возможными ориентировками осей сжатия и растяжения, так как в них запечатлены все этапы деформации, которой подверглась территория. Однако характер распределения восстановленных нами ориентировок осей сжатия и

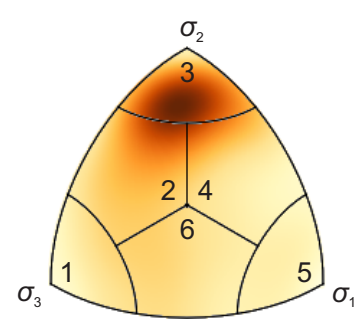

Рис. 6. Плотность выхода направления на зенит относительно главных осей напряжений для изученных пунктов геологоструктурных наблюдений.

Цветом показана плотность точек на диаграмме: темные оттенки красного - высокая плотность, светлые оттенки желтого - низкая плотность. 1 - горизонтальное растяжение; 2 горизонтальное растяжение со сдвигом; 3 - горизонтальный сдвиг; 4 - горизонтальное сжатие со сдвигом; 5 - горизонтальное сжатие; 6 - вертикальный сдвиг.

Fig. 6. Density of the direction to the zenith relative to the main stress axes for the studied geological and structural observation points.

Density of points in the diagram: dark shade red - high, light yellow low. 1 - horizontal tension; 2 - horizontal tension with shear; 3 horizontal shear; 4 - horizontal compression with shear; 5 - horizontal compression; 6 - vertical shear.

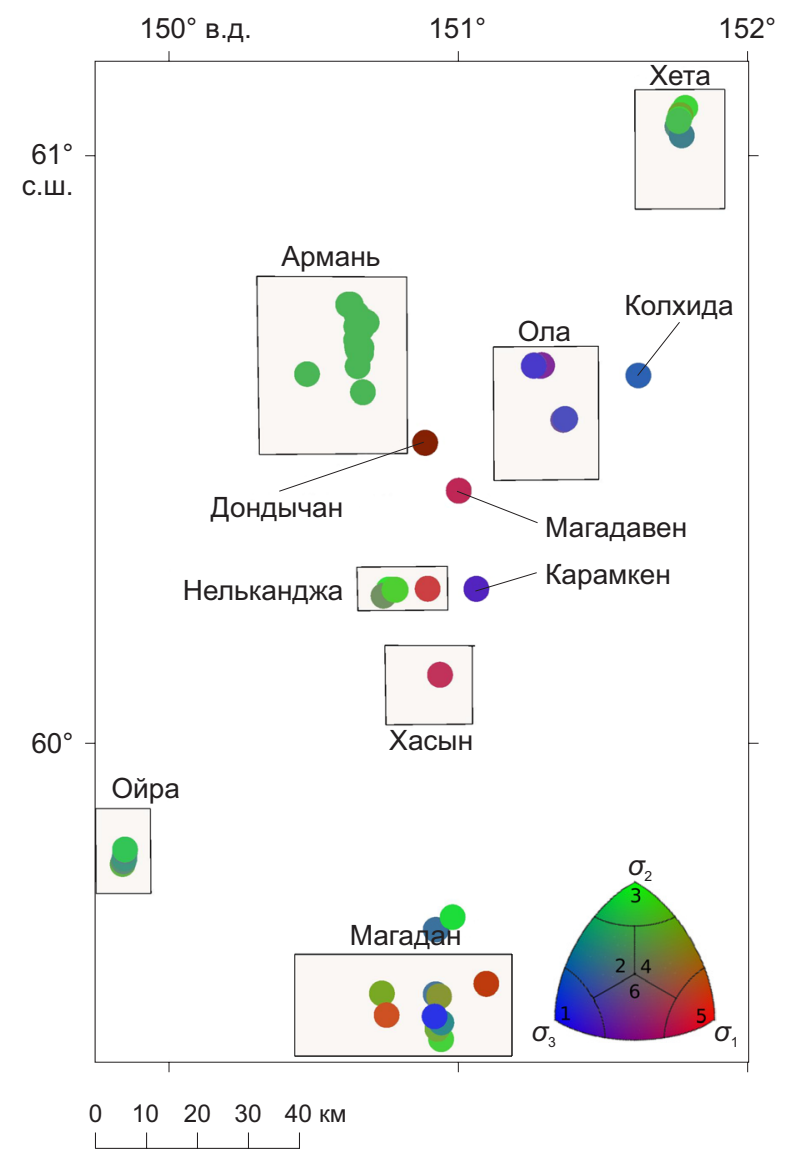

Рис. 7. Типы напряженных состояний на изученных участках в зависимости от положения оси на зенит относительно осей главных напряжений.

1 - горизонтальное растяжение; 2 - горизонтальное растяжение со сдвигом; 3 - горизонтальный сдвиг; 4 - горизонтальное сжатие со сдвигом; 5 - горизонтальное сжатие; 6 - вертикальный сдвиг.

Fig. 7. Types of the stress state depending on the position of the axis to the zenith relative to the main stress axes.

1 - horizontal tension; 2 - horizontal tension with shear; 3 - horizontal shear; 4 - horizontal compression with shear; 5 - horizontal compression; 6 - vertical shear. 
растяжения не проявляет ожидаемого закономерного усложнения при переходе от более молодых структур к более древним.

Если существенное влияние оказывает рисунок сети активных разломов, то вариации поля напряжений могут быть объяснены не изменением деформации во времени, а особенностями разломно-блокового строения территории, что приводит к закономерному «преломлению» приложенных напряжений. На территории Северного Приохотья наблюдаются активные разломы разной ориентировки и кинематики - северо-западные сдвиги, субширотные сбросы с разным положением в геологической структуре территории. В случае, если верен этот сценарий, должна наблюдаться устойчивая связь разломов и поля напряжений в зоне их влияния.

Для проверки влияния этого фактора была составлена табл. 2, в которой показано сочетание напряженных состояний для пунктов геолого-структурных наблюдений, находящихся в зоне влияния разломов различной ориентировки. Представив ее как таблицу сопряженности, можно провести анализ частот, используя критерий $\chi^{2}$ для оценки зависимости частот встречаемости различных напряженных состояний от геологической структуры. В качестве нулевой гипотезы принимается, что такая зависимость отсутствует. Р-значение, рассчитанное для критерия $\chi^{2}$, для указанной таблицы составляет 0.4576. Таким образом, мы не можем отвергнуть нулевую гипотезу, а значит, между напряженными состояниями на территории Северного Приохотья и зонами динамического влияния активных разломов различной ориентировки отсутствует статистически достоверная связь и у нас нет оснований для учета этого фактора.

Для оценки влияния фактора геологической структуры была составлена табл. 3, в которой показано сочетание напряженных состояний для разных геологических структур, восстановленных в ходе полевых исследований. Представив ее как таблицу сопряженности, можно провести анализ частот, используя критерий $\chi^{2}$ для оценки зависимости частот встречаемости различных напряженных состояний от геологической структуры. В качестве нулевой гипотезы принимается, что такая зависимость отсутствует. Рассчитанное р-значение критерия $\chi^{2}$ для указанной таблицы составляет 0.02523 , что означает, что у нас есть все основания отвергнуть нулевую гипотезу и принять предположение, что между геологическими структурами разного возраста на территории Северного Приохотья и стресс-состояниями разного типа существует статистически достоверная связь. Таким образом, мы можем считать, что основным фактором, объясняющим распределение напряженных состояний на территории Северного Приохотья, является геологическое строение.

Для оценки общего напряженного состояния, характерного для каждой из геологических структур, был применен метод Л.А. Сим (рис. 8). Подбор конусов сжатия и растяжения осуществляли методом наименьших квадратов. Установленные ориентации конусов показывают следующее:

- для складчатых структур Армано-Вилигинского синклинория характерно четко выраженное поле напряжений типа горизонтального сдвига с осью сжатия в субширотном направлении (аз. $67^{\circ}$, угол $12^{\circ}$ ) и растяжения в субмеридиональном направлении (аз. $161^{\circ}$, угол $19^{\circ}$ );

- структурам Хасыно-Момолтыкичской зоны УдскоМургальской дуги свойственны напряженные состояния

Таблица 2. Частота встречаемости различных напряженных состояний в зависимости от приуроченности участка к зонам влияния активных разломов разного простирания

Table 2. Occurrence frequency of stress states with respect to confinement of the studied sites to the zones of influence of active faults differing in strike

\begin{tabular}{lcccc}
\hline $\begin{array}{l}\text { Простирание } \\
\text { разлома }\end{array}$ & 12 & 4 & 1 \\
\hline Субширотное & 6 & 8 & 0 & 1 \\
С3 и Св & 3 & $\sum=35, \mathrm{p}=0.4576$ & & \\
& & & \\
& &
\end{tabular}

Примечание. Положение центра черного сегмента на шарике в заголовке таблицы отвечает выходу оси $\sigma_{1}$, положение центра белого сегмента отвечает выходу оси $\sigma_{3}$.

Note. In the table header, centers of ball segments: black - axis $\sigma_{1}$; white axis $\sigma_{3}$.

Таблица 3. Частота встречаемости различных напряженных состояний в зависимости от приуроченности участка к геологической структуре

Table 3. Occurrence frequency of stress states with respect to confinement of the studied sites to geological structures

\begin{tabular}{lccccc}
\hline Участок & 8 & 1 & 0 & 0 \\
\hline АВС & 3 & 7 & 1 & 1 & 0 \\
Удско-Мургальская дуга & 2 & 4 & 0 & 0 & 3 \\
ОчвП & 3 & 0 & $\sum=46, \mathrm{p}=0.02523$
\end{tabular}

Примечание. Положение центра черного сегмента на шарике в заголовке таблицы отвечает выходу оси $\sigma_{1}$, положение центра белого сегмента отвечает выходу оси $\sigma_{3}$.

Note. In the table header, centers of ball segments: black - axis $\sigma_{1}$; white - axis $\sigma_{3}$. 

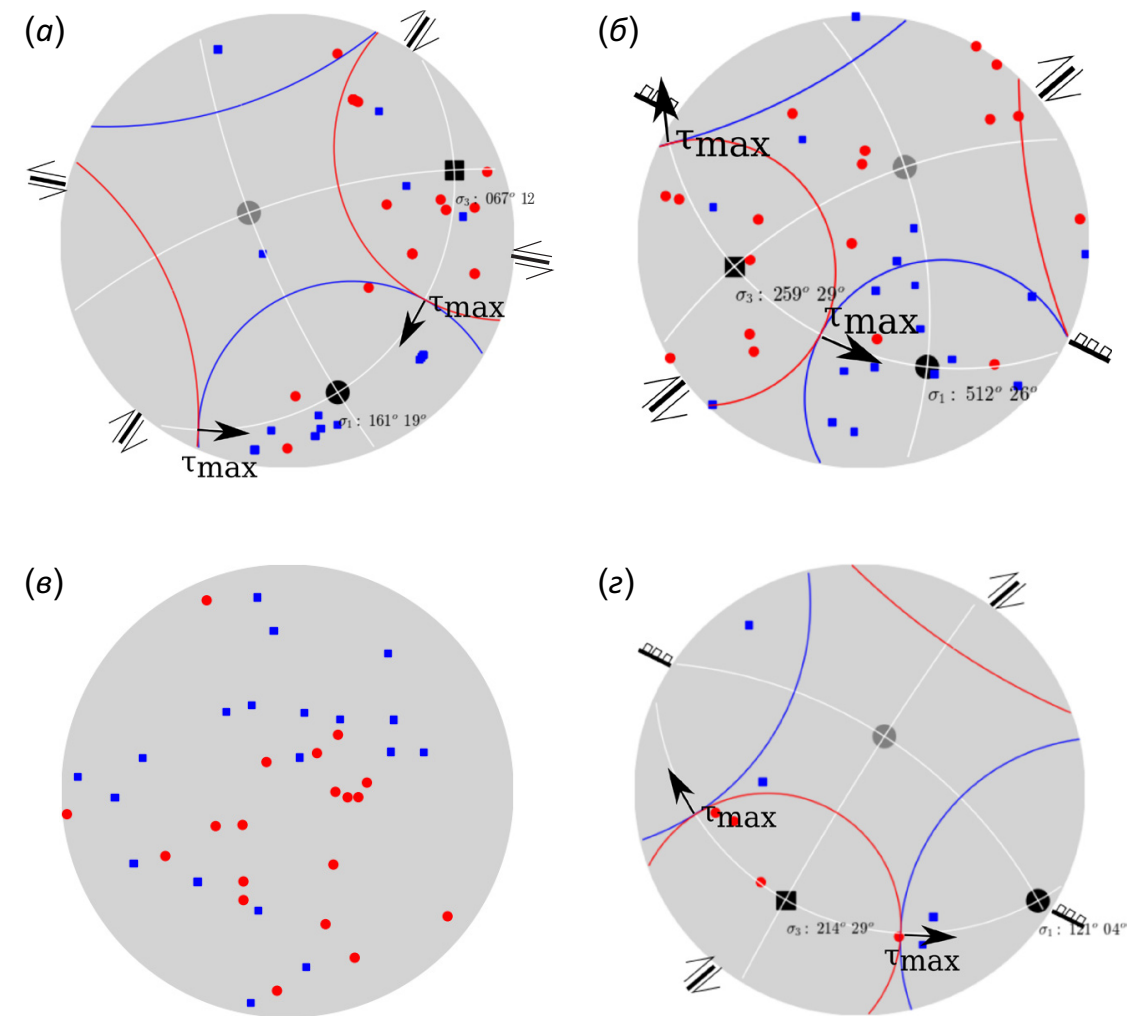

Рис. 8. Стереограммы напряженных состояний в зависимости от приуроченности к одной из тектонических структур Северного Приохотья (сетка Вульфа, нижняя полусфера).

(a) - складчатые структуры Армано-Вилигинского синклинория, (б) - структуры Хасыно-Момолтыкичской зоны УдскоМургальской дуги, (8) - вулканоструктуры ОЧВП, (2) - кайнозойские впадины.

Fig. 8. Stereograms of the stress state depending on confinement to one of the tectonic structures of the Northern Priokhotie (lower hemisphere, Wulf net).

(a) - folded structures of the Arman-Viliga synclinorium, (б) - structures of the Khasyn-Momoltykich zone of the Uda-Murgal arc, ( 8 ) volcanic structures of the Okhotsk-Chukotka volcanogenic belt (ОЧВП), (2) - Cenozoic depressions.

типа горизонтального растяжения со сдвигом с осью сжатия в северо-западном направлении (аз. $259^{\circ}$, угол $29^{\circ}$ ) и осью растяжения - в северо-восточном (аз. $152^{\circ}$, угол $26^{\circ}$ );

- вулканоструктуры Хасынского звена ОЧВП характеризуются изменчивым полем тектонических напряжений с вариациями типа напряженного состояния от горизонтального сдвига до горизонтального растяжения;

- для кайнозойских впадин миоцен-плиоценового возраста характерны напряженные состояния сдвигового типа с осью сжатия в северо-восточном направлении (аз. $214^{\circ}$, угол. $29^{\circ}$ ) и осью растяжения в северозападном направлении (аз. $121^{\circ}$, угол. $04^{\circ}$ ).

На итоговых стереограммах напряженных состояний (рис. 8) для Армано-Вилигинского синклинория и Хасыно-Момолтыкичской зоны присутствуют отдельные напряженные состояния, для которых не выполняется правило, согласно которому выходы осей напряжений должны располагаться в одноименных конусах (три напряженных состояния на рис. 8, а, и два на рис. 8, б). Возможным объяснением этому является либо ошибочная интерпретация матриц плотностей трещиноватости (в центральной части разломной зоны на участках
Хета и на Армань), либо то, что указанные решения были получены для пунктов наблюдений, находящихся вдали от разломных зон (участок Магадан-1).

Выявленные напряженные состояния типа горизонтального сдвига с осью сжатия в субширотном направлении хорошо согласуются с параметрами напряженнодеформированного состояния Охотской микроплиты, полученными по данным GPS- и сейсмического мониторинга [Fujita et al., 2009; Hindle, Mackey, 2011]. Указанный характер деформации может быть объяснен экструзией Охотской плиты к югу за счет сдавливания ее северного сектора Северо-Американской и Евразийской тектоническими плитами [Riegel et al., 1993].

\section{5. ЗАКЛЮЧЕНИЕ}

В результате изучения тектонических напряжений в мезо-кайнозойских структурах Северного Приохотья и их сравнительного анализа установлено, что их разнообразие контролируется положением в региональной геологической структуре, а именно: как мезозойским складчатым структурам основания ОЧВП, так и кайнозойским структурам межгорных впадин свойственны напряженные состояния с осью сжатия, ориентированной субширотно (горизонтальный сдвиг и 
горизонтальное растяжение со сдвигом). При этом вулканоструктуры самого ОЧВП характеризуются изменчивым полем напряженных состояний. Восстановленное напряженное состояние хорошо согласуется с параметрами напряженно-деформированного состояния Охотской микроплиты, полученными по данным GPS и сейсмического мониторинга.

\section{6. ЛИТЕРАТУРА/REFERENCES}

Akinin V.V., Miller E.L., 2011. Evolution of Calc-Alkaline Magmatism of the Okhotsk-Chkotka Volcanogenic Belt. Petrology 19 (3), 249-292 (in Russian) [Акинин В.В., Миллер Э.Л. Эволюция известково-щелочного магматизма Охотско-Чукотского вулканогенного пояса // Петрология. 2011. Т. 19. № 3. С. 249-292].

Fujita K., Koz'min B.M., Mackey K.G., Riege S.A., McLean M.S., Imaev V.S., 2009. Seismotectonics of the Chersky Seismic Belt, Eastern Sakha Republic (Yakutia and Magadan District, Russia). In: D.B. Stone, K. Fujita, P.W. Layer, E.L. Miller, A.V. Prokopiev, J. Toro (Eds), Geology, Geophysics and Tectonics of Northeastern Russia: A Tribute to Leonid Parfenov. Stephan Mueller Special Publication Series 4, 117-145. https://doi. org/10.5194/smsps-4-117-2009.

Goryachev N.A., 2005. The Uda-Murgal Magmatic Arc: Geology, Magmatism, Metallogeny. In: V.I. Goncharov, V.M. Kuznetsov (Eds), Problems of Metallogeny of Ore Regions of the Northeastern Regions of Russia. North East Interdisciplinary Scientific Research Institute FEB RAS, Magadan, 1737 (in Russian) [Горячев Н.А. Удско-Мургальская магматическая дуга: геология, магматизм, металлогения // Проблемы металлогении рудных районов северо-востока России / Ред. В.И. Гончаров, В.М. Кузнецов. Магадан: СВКНИИ ДВО РАН, 2005. С. 17-37].

Grinenko O.V., Sergeenok A.I., Belolyubsky I.N., 1998. Paleogene and Neogene of the Northeastern Regions of Russia. Vol. 1. Yakutian Scientific Center SB RAS, Yakutsk, 36 p. (in Russian) [Гриненко O.В., Сергеенок А.И., Белолюбский И.Н. Палеоген и неоген северо-востока России. Якутск: ЯНЦ CO PAH, 1998. Ч. 1. 36 с.].

Hindle D., Fujita K., Mackey K.G., 2009. Deformation of the Northwestern Okhotsk Plate: How Is It Happening? In: D.B. Stone, K. Fujita, P.W. Layer, E.L. Miller, A.V. Prokopiev, J. Toro (Eds), Geology, Geophysics and Tectonics of Northeastern Russia: A Tribute to Leonid Parfenov. Stephan Mueller Publication Series 4, 147-156. https://doi.org/10.5194/ smsps-4-147-2009.

Hindle D., Mackey K., 2011. Earthquake Recurrence and Magnitude and Seismic Deformation of the Northwestern Okhotsk Plate, Northeast Russia. Journal of Geophysical Research: Solid Earth 116 (B2) https://doi.org/10.1029/201 0JB007409.

Khanchuk A.I. (Ed.), 2006. Geodynamics, Magmatism and Metallogeny of the Eastern Regions of Russia. Dal'nauka, Vladivostok, 981 p. (in Russian) [Геодинамика, магматизм и металлогения востока России / Ред. А.И. Ханчук. Владивосток: Дальнаука, 2006. 981 с.].

Kondratyev M.N., 2015. The Use of an Additional Statistical Criterion for Assessing the Reliability of the Choice of
Conjugated Planes in the Analysis of Fracture Matrices by the Nikolaev Method. In: Modern Tectonophysics. Methods and Results. Materials of the Fourth Youth Tectonophysical School-Workshop (October 05-09, 2015). Vol. 1. IPE, Moscow, p. 162-165 (in Russian) [Кондратьев М.Н. Использование дополнительного статистического критерия для оценки достоверности выбора сопряженных плоскостей при анализе матриц трещиноватости методом Николаева // Современная тектонофизика. Методы и результаты: Материалы Четвертой молодежной тектонофизической школы-семинара (05-09 октября 2015 г.). М.: ИФЗ, 2015. Т. 1. С. 162-165].

Kondratyev M.N., 2019. Comparative Analysis of Tectonic Stresses in the Late Mesozoic and Cenozoic Structures of Northern Priokhotie. Brief PhD Thesis (Candidate of Geology and Mineralogy). Magadan, 24 p. (in Russian) [Кондратьев М.Н. Сравнительный анализ тектонических напряжений в структурах позднего мезозоя и кайнозоя в Северном Приохотье: Автореф. дис ... канд. геол.-мин. наук. Магадан, 2019. 24 с.].

Kondratyev M.N., Smirnov V.N., 2013. Tectonic Stress Fields in the Basement Structures of the Okhotsk-Chukotka Volcanogenic Belt (Northern Priokhotye). Bulletin of the North-Eastern Scientific Center of FEB RAS 4, 23-27 (in Russian] [Кондратьев М.Н., Смирнов В.Н. Поля тектонических напряжений в структурах основания Охотско-Чукотского вулканогенного пояса (Северное Приохотье)// Вестник СВНЦ ДВО РАН. 2013. № 4. С. 23-27].

Kotlyar I.N., Rusakova T.B., 2004. Cretaceous Magmatism and Ore Potential of the Okhotsk-Chukotka Region: Geological and Geochronological Correlation. North East Interdisciplinary Scientific Research Institute FEB RAS, Magadan, 152 p. (in Russian) [Котляр И.Н., Русакова Т.Б. Меловой магматизм и рудоносность Охотско-Чукотской области: геолого-геохронологическая корреляция. Магадан: СВКНИИ ДВО РАН, 2004. 152 с.].

Nikolaev P.N., 1977. Methods of Statistical Analysis of Fractures and Reconstruction of Tectonic Stresses. Proceedings of Higher Educational Establishments. Geology and Exploration 12, 103-115 (in Russian) [Николаев П.Н. Методика статистического анализа трещин и реконструкция полей напряжений // Известия вузов. Геология и разведка. 1977. № 12. С. 103-115].

Rebetsky Yu.L., Sim L.A., Marinin A.V., 2017. From Slickensides to Tectonic Stress. Techniques and Algorithms. GEOS, Moscow, 234 p. (in Russian) [Ребецкий Ю.Л., Сим Л.А., Маринин A.В. От зеркал скольжения к тектоническим напряжениям. Методики и алгоритмы. М.: ГЕОС, 2017. 234 с.].

Riegel S., Fujita K., Koz'min B.M., Imaev V.S., Cook D.B., 1993. Extrusion Tectonics of the Okhotsk Plate, Northeast Asia. Geophysical Research Letters 20 (7), 607-610. https:// doi.org/10.1029/93GL00267.

Seno T., Sakurai T., Stein S., 1996. Can the Okhotsk Plate Be Discriminated from the North American Plate? Journal of Geophysical Research: Solid Earth 101 (B5) 11305-11315. https://doi.org/10.1029/96JB00532.

Sim L.A., 1982. Determination of the Regional Stress Field from the Data on Local Stress Fields on Separate Sites 
(Example of the Junction Zone of the Mezen Syneclise and the Middle Timan). Proceedings of Higher Educational Establishments. Geology and Exploration 4, 35-40 (in Russian) [Сим Л.А. Определение регионального поля напряжений по данным о локальных полях напряжений на отдельных участках (на примере зоны сочленения Мезенской синеклизы и Среднего Тимана) // Известия вузов. Геология и разведка. 1982. № 4. С. 35-40].

Smirnov V.N., 2006. Geological Structure, Modern Tectonics and Seismic Activity. In: Landscapes, Climate and Natural Resources of the Tauis Bay, the Sea of Okhotsk. Dal'nauka, Vladivostok, p. 39-50 (in Russian) [Смирнов B.H. Геологическое строение, новейшая тектоника и сейсмическая активность // Ландшафты, климат и природные ресурсы Тауйской губы Охотского моря. Владивосток: Дальнаука, 2006. С. 39-50].

Smirnov V.N., Glushkova O.Yu., Kolegov P.P., Kondratyev M.N., 2017. Paleoseismic Dislocations in the Dondychan River Basin (Northern Priokhotye). Bulletin of the NorthEastern Scientific Center of FEB RAS 2, 41-50 (in Russian) [Смирнов В.Н., Глушкова О.Ю., Колегов П.П., Кондратьев М.Н. Палеосейсмодислокации в бассейне р. Дондычан (Северное Приохотье) // Вестник СВНЦ ДВО РАН. 2017. № 2. C. 41-50].

Smirnov V.N., Glushkova O.Yu., Pakhomov A. Yu., 2000. Landslide Processes in the Zone of the Nagaev Active Fault (City of Magadan Area). In: Proceedings of IV Shchukin Readings. Geomorphology on the Edge of the 21st Century. Publishing House of Geographical Faculty of MSU, Moscow, p. 88-92 (in Russian) [Смирнов В.Н., Глушкова О.Ю., Пахомов А.Ю. Оползневые процессы в зоне Нагаевского активного разлома (район г. Магадана) // IV Щукинские чтения: Геоморфология на рубеже XXI века: Труды
Всероссийской конференции. М.: Изд-во географического факультета МГУ, 2000. С. 340-343].

Smirnov V.N., Kondratyev M.N., 2011. The Stress Field and Inner Structures of the Khetinsky Active Fault Area. Bulletin of the North-Eastern Scientific Center of FEB RAS 4, 65-72 (in Russian) [Смирнов В.Н., Кондратьев М.Н. Поле напряжений и внутренняя структура Хетинского активного разлома // Вестник СВНЦ ДВО РАН. 2011. № 4. C. 65-72].

Smirnov V.N., Kondratyev M.N., Kolegov P.P., 2018. A Large Paleoseismodislocation in the Southeastern Part of the Cherskii Seismic Belt, Northern Priokhotye. Doklady Earth Sciences 479 (2), 425-428. https://doi.org/10.1134/ S1028334X18040104.

State Geological Map, 1992. Scale 1:1000000. Sheets 0-56 (Magadan), P-56, P-57 (Seimchan). Explanatory Note. VSEGEI, Saint Petersburg, 112 p. (in Russian) [Государственная геологическая карта. Масштаб 1:1000000. Листы 0-56 (Магадан), P-56, P-57 (Сеймчан): Объяснительная записка. СПб.: ВСЕГЕИ, 1992. 112 с.].

State Geological Map, 2001. Scale 1:200000. Magadan Series. Sheets P-56-XXXI, XXXII, 0-56-I, 0-56-II. Explanatory Note. VSEGEI, Saint Petersburg, 258 p. (in Russian) [Государственная геологическая карта. Серия Магаданская. Масштаб 1:200000. Листы P-56-XXXI, XXXII, 0-56-I, 0-56-II: Объяснительная записка. СПб.: ВСЕГЕИ, 2001. 258 c.].

State Geological Map of the Russian Federation, 2008. Verkhoyansk-Kolyma Series. Scale 1:1000000. Sheet P-56 (Seimchan). VSEGEI, Saint Petersburg (in Russian) [Государственная геологическая карта Российской Федерации. Масштаб 1:1000000. Серия Верхояно-Колымская. Лист Р-56 (Сеймчан). СПб.: ВСЕГЕИ, 2008]. 